\title{
Study on Technological Innovation Pattern Based on Norton model
}

\author{
Zhang Jie \\ Dept. of Economy and Trade \\ Chongqing University of Technology \\ Chongqing , P.R.China 400054 \\ zhangjie@cqut.edu.cn
}

\begin{abstract}
There are two kinds of the technology innovation mode of automobile industry, that is the joint innovation and Self-innovation. Their effectiveness of innovation and market value can be obtained from diffusion. In this paper, characteristics of two kinds of innovation mode are analyzed, and the calculation results are compared based on Norton model by automobile market data for Chongqing. The results show that products of self-innovation are spread rapidly by the joint innovation, and their products can be balanced in market. It show that the relationship between the joint innovation and the self-innovation, and there is intense competition between them. Therefore, the ways of innovation can be improved to promote the ability of selfinnovation of enterprises.
\end{abstract}

Keywords-Technology innovation,Joint innovation, Selfinnovation, Norton model,Diffusion of Product

\section{INTRODUCTION}

This template, There are two kinds of the technology innovation pattern in the process of the development of automobile industry in China ,that is the joint innovation, and self-innovation.Thedomestic automobile production situation is completely changed by two kinds of thetechnology innovation. Joint innovation has played an extremely important role In the domestic automotive technology in the process of growth.

In the paper [2], characteristics of two kinds of innovation mode are analyzed by automobile market data for Chongqing, and the calculation results are compared based on BASS model in paper. The results show that there is the relationship between the Joint innovation and the self innovation, and there is the same change. Also there is intense competition between them.

In this paper the relationship between the two is further researched. Their market value were compared based on Norton model of for diffusion theory of new produc. the interaction between the two types of innovation is measured through the empirical study.. So that we understand the relationship between them, and use effect of innovation diffusion reasonably to prevent the negative effects of overflow. and improve the ability of independent innovation of enterprises to promote the innovation ability the country.

\section{CHARACTERISTICS OF JOINT INNOVATION AND SELF- INNOVATION}

Reverse engineering and imitative innovation is a key feature of the self-innovation of automobile.From the beginning of China's first car to the automobile industry at present,to meet the needs of the market, which is the most economical and convenient way of development of products.

The imported production line of automobile from foreign is important feature of the self- innovation of automobile. Enterprises is not only the purchase of production equipment, but also obtain the intellectual property rights.

Manufacturers can develop new products in less time, can improve the design according to the needs of the market.However, products may be products of older.

It is not easy to obtain advanced technology, so that the car can not be competitive on the international market..Both self-innovation of automobile or joint venture automobile, their technology source are from advanced technology of foreign production.

Their characteristics are quite different in product development, brand and marketing . self- innovation of automobile can have the initiative and control power fully, but the joint car in these areas subject to the joint venture Because the self-innovation is obviously a disadvantage in technology, so the low price has become an important feature of the selfinnovation of automobile. The characteristics of the two as shown in the following table 1.

Although the joint venture automobile was installed,and a few parts of production have been made in the domestic, but has almost no independent right, control right in terms of technology, and a lot of allocation to foreign in profit. Joint venture automobile had lost the "market for technology" , become a tool of foreign car to have home market profits. 


\section{NORTON MODEL OF MULTI GENERATION PRODUCT DIFFUSION}

First, If we were to take an empirical study on the joint innovation products and self-innovation products with BASS model,that the interaction between the two kinds of products be ignored and stimate the external factors are exaggerated.

TABLE I THE COMPARE OF SELF-INNOVATION CAR AND JOINT VENTURE CAR

\begin{tabular}{|c|c|c|}
\hline & self-innovation car & joint venture car \\
\hline $\begin{array}{l}\text { Technolo } \\
\text { gy } \\
\text { source }\end{array}$ & $\begin{array}{l}\text { Buy production mold of } \\
\text { foreign car directly,Imitate } \\
\text { foreign products in reverse } \\
\text { engineering. }\end{array}$ & $\begin{array}{l}\text { imported production line with } \\
\text { the way of joint venture }\end{array}$ \\
\hline $\begin{array}{l}\text { Technolo } \\
\text { gy } \\
\text { control }\end{array}$ & $\begin{array}{l}\text { Manufacturers have the } \\
\text { right of production } \\
\text { technology to ownership } \\
\text { and use }\end{array}$ & $\begin{array}{l}\text { The production technology is } \\
\text { controlled by the joint venture }\end{array}$ \\
\hline $\begin{array}{l}\text { Product } \\
\text { develop } \\
\text { ment }\end{array}$ & $\begin{array}{l}\text { Because the direct } \\
\text { purchase or imitation, so } \\
\text { ability of product } \\
\text { development is weak }\end{array}$ & $\begin{array}{c}\text { The joint venture company } \\
\text { does not have the ability of } \\
\text { product development, can } \\
\text { only have adaptability } \\
\text { improvement of product }\end{array}$ \\
\hline $\begin{array}{l}\text { Tradema } \\
\text { rk right }\end{array}$ & $\begin{array}{l}\text { With independent } \\
\text { intellectual property } \\
\text { rights,and has the } \\
\text { ownership and the use } \\
\text { right of trademark } \\
\end{array}$ & $\begin{array}{l}\text { The use of the trademarks of } \\
\text { joint venture , or add the } \\
\text { name of the trademark in } \\
\text { china. Trademark belonging } \\
\text { to the joint venture }\end{array}$ \\
\hline $\begin{array}{l}\text { Intangibl } \\
\text { e value }\end{array}$ & $\begin{array}{l}\text { Most cars is new, there is } \\
\text { no basis for market, } \\
\text { intangible value of } \\
\text { products is probably } \\
\text { affected by imitation. }\end{array}$ & $\begin{array}{l}\text { Models designed by } \\
\text { historical models evolved,and } \\
\text { has a good reputation.As the } \\
\text { foreign joint venture has a } \\
\text { long production history, so } \\
\text { product has higher intangible } \\
\text { value. }\end{array}$ \\
\hline $\begin{array}{l}\text { Marketin } \\
\text { g }\end{array}$ & $\begin{array}{l}\text { Independentn production } \\
\text { companies can control } \\
\text { marketing of products }\end{array}$ & $\begin{array}{l}\text { The joint venture control right } \\
\text { of product marketing in } \\
\text { global perspective.So the } \\
\text { choice of appropriate models } \\
\text { to product in the Chinese.And } \\
\text { appropriate to launch } \\
\text { replacement products. }\end{array}$ \\
\hline $\begin{array}{l}\text { Market } \\
\text { positioni } \\
\text { ng }\end{array}$ & $\begin{array}{c}\text { The product is } \\
\text { concentrated on the middle } \\
\text { and low market, low prices } \\
\text { as the main means of } \\
\text { competition }\end{array}$ & $\begin{array}{l}\text { productes coverage all market } \\
\text { in domestic. }\end{array}$ \\
\hline
\end{tabular}

Norton model for diffusion of new product is applied in the study of related product diffusion. It is the first generation of products the user will become the potential users of the next generation of products, which is based on the Bass diffusion model of superimposed on a generation ofproduct users, through this way to express the relationship between the two generation productsubstitution.Norton model assumes that the second generation of products to replace the previous generation products, as well as each generation of internal and external factorsof the sameproduct, The relationship between the joint venture and innovation, independent innovation and competition between alternative is inconsistent.

So, instead of competition with variable $c_{i j} F_{j}(t)$ on the generation of user model in Norton to replace [3]. The process of diffusion of joint innovation car was affected by self-innovation car through its cumulative purchase quantity according to certain rules ( $C_{i j}$ ) [4], the formula is as follows:

confirm that you have the correct template for your paper size. This template has been tailored for output on the A4 paper size. If you are using US letter-sized paper, please close this file and download the file "MSW_USltr_format".

$$
\left\{\begin{array}{l}
d F_{1}(t) / d t=\left[p_{1}^{*}+q_{1}^{*} F_{1}(t)+c_{12}^{*} F_{2}(t)+\varepsilon_{1}\right]\left[m-F_{1}(t)-F_{2}(t)\right] \\
d F_{2}(t) / d t=\left[p_{2}^{*}+q_{2}^{*} F_{2}(t)+c_{21}^{*} F_{1}(t)+\varepsilon_{2}\right]\left[m-F_{1}(t)-F_{2}(t)\right]
\end{array}\right.
$$

$C_{12}, C_{21}$ are influencing factors between self-innovation and joint innovation, $\varepsilon_{1}, \varepsilon_{2}$ are other does the factors of influencing the diffusion, $\mathrm{M}$ is diffusion total of two products.

\section{DIFFUSION OF JOINT INNOVATION AND SELF - INNOVATION BASED ON NORTON MODEL}

Firstly, joint innovation, independent innovation of automobile is considered a whole product family, then total amount of potential users was calculated by bass model with total of Chongqing automobile From 1998 to 2011.

TABLE II THE DIFFUSION GROUP AND SPEED ESTIMATED IN CHONGQINg

\begin{tabular}{|c|c|c|c|c|}
\hline coefficient & $\beta_{1}$ & $\beta_{2}$ & $\beta_{3}$ & $R^{2}$ \\
\hline Estimated value & 554.3784 & $\begin{array}{c}0.387146^{*} \\
*\end{array}$ & $-2.41 \mathrm{E}-08^{*}$ & $99 \%$ \\
\hline coefficient & $R^{2}$ & $p$ & $q$ & $m$ \\
\hline Estimated value & $99 \%$ & 0.000035 & 0.385072 & 16065581 \\
\hline
\end{tabular}

The positive and negative of coefficient estimated are consistent with the expected, only $\boldsymbol{\beta}_{2}, \boldsymbol{\beta}_{3}$ in three coefficients were significantly different from zero in statistically, R2 was up to $99 \%$, diffusion is better more than independent diffusion estimated.

Diffusion capacity of Chongqing automobile market is about 16070000 vehicles $(m=16065581)$ In the absence of repeat purchase.Potential users by external factors are about $0.004 \%$ a year $(\mathrm{p}=0.000035)$; potential users by internal factors are about 39\% $\mathrm{F}(\mathrm{T})$ of $/ \mathrm{m}$ each year $\quad(q=0.385072)$. Two types of innovation diffusion car will are 1550000, which is expected to peak in 2022,then decreased year by year. When $\mathrm{m}=16065581$ in the diffusion model, the The value 
was estimated by Linear regression method .The results are as followsas:

TABLE III ESTIMATED PARAMETER IN DIFFUSION MODEL OF JOINT INNOVATION CAR AND SELF- INNOVATION CAR IN CHONGQING

\begin{tabular}{|l|l|l|}
\hline \multirow{2}{*}{ coefficient } & \multicolumn{2}{|c|}{ Pattern } \\
\cline { 2 - 3 } & joint innovation car & self- innovation car \\
\hline$p^{*}$ & $0.000645^{* *}$ & -0.002682 \\
\hline$q^{*}$ & $2.07 \mathrm{e}-8^{* *}$ & $1.99 \mathrm{E}-08$ \\
\hline$c^{*}$ & $-5.23 \mathrm{E}-09$ & $6.22 \mathrm{E}-09$ \\
\hline$R^{2}$ & $99 \%$ & $98 \%$ \\
\hline
\end{tabular}

$\mathrm{p}^{*}, \mathrm{q}^{*}$ coefficient is positive of joint innovation of automobile, significant, and diffusion characteristics in accordance with the standards of the market;

Potential users by external factors are about $0.004 \%$ a year $(\mathrm{p}=0.000035)$; potential users by internal factors are about $39 \% \mathrm{~F}(\mathrm{~T})$ of $/ \mathrm{m}$ each year $(\mathrm{q}=0.385072)$. Two types of innovation diffusion car will are 1550000, which is expected to peak in 2022,then daffects diffusionof joint innovation car was blocked by information of purchased selfinnovation car.

The diffusion coefficient of self-innovation of Chongqing cars are not significant, but significant levels of $\mathrm{q}^{*}, \mathrm{c}^{*}$ is not high, are a little more than 20\%; $\mathrm{P}^{*}$ is negative, the effect of external factors of self innovation of automobile is the negative for growth of potential users . $\mathrm{q}^{*}=1.99 \mathrm{e}-8$, it was obviously less than the value obtained from independent diffusion( $\mathrm{q}=4.07 \mathrm{e}-7)$, This shows that the effect on internal factors of self- innovation obtained from independent diffusion is overrated;

c* is a relevant factor of joint innovation car, This value is very small, but the diffusion of self innovation of automobile was The diffusion of self innovation of automobile is amplified. By number of buyers for joint innovation car .

\section{BALANCE OF MARKET DIFFUSION}

The estimated values of the parameters into Norton model, the results are as follows:

$$
\left\{\begin{array}{l}
\frac{d F_{1}(t)}{d t}=\left[0.000645+2.07 e^{-8} F_{1}(t)-5.23 e^{-9} F_{2}(t)\right]\left[16065581-F_{1}(t)-F_{2}(t)\right] \\
\frac{d F_{2}(t)}{d t}=\left[-0.002682+1.99 e^{-8} F_{2}(t)+6.22 e^{-9} F_{1}(t)\right]\left[16065581-F_{1}(t)-F_{2}(t)\right]
\end{array}\right.
$$

If first derivative of F1, F2 is zero, the equation is as follows::

$$
\left\{\begin{array}{l}
\text { if } \frac{d F_{1}(t)}{d t}=0, F_{1}(t)=0.25 F_{2}(t)-224640 F_{1}(t)=16065581-F_{2}(t) \\
\text { if } \frac{d F_{2}(t)}{d t}=0, F_{1}(t)=-0.03 F_{2}(t)+43119 o F_{2}(t)=16065581-F_{1}(t)
\end{array}\right.
$$

drawing functions (F1, F 2, t) when first derivative of $\mathrm{F} 1, \mathrm{~F} 2$ is zero in the F1-F2 plane .EG is trajectory as of the function of when $F 1(T)=16065581-F 2(T), \quad F 1^{\prime}(t)=0$ 、 $F 2^{\prime}(t)=0, A C, B D$ is trajectory as of the function of when $\mathrm{F} 1(\mathrm{t})=0.25 \mathrm{~F} 2(\mathrm{t})-22464, \mathrm{~F} 1(\mathrm{t})=-0.03 \mathrm{~F} 2(\mathrm{t})+43119$. The direction of changed trajectory was represented with arrows in this diagram.

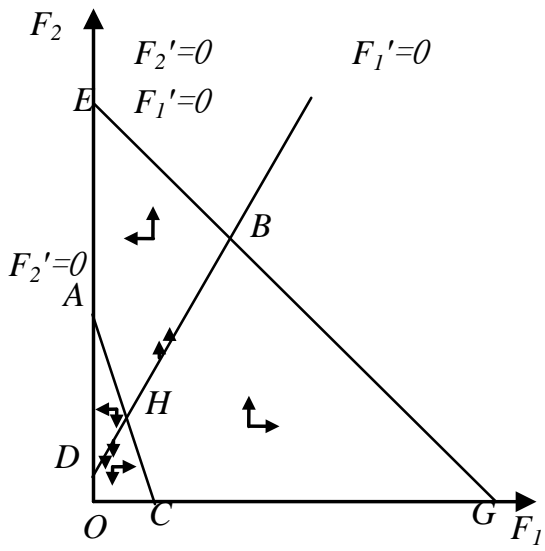

Fig 1 phase diagram of car diffusion

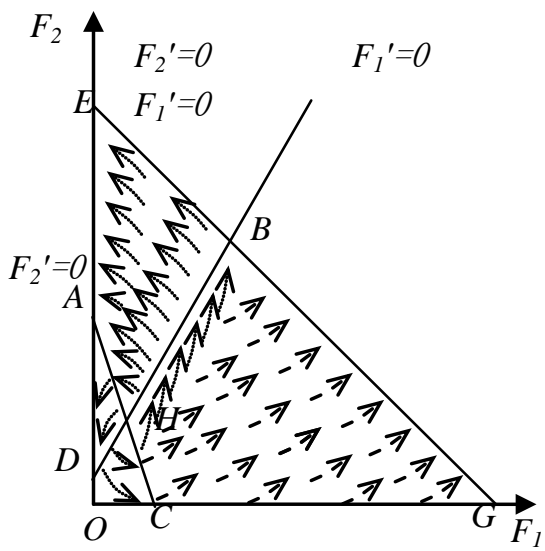

Fig 2 Market equilibrium

All Points in the range of $\triangle$ EGO represents the cumulative sales of Self-innovation car and the joint innovation car.Obviously, all singularities are not equilibrium point, will be able to achieve market equilibriumonly on point $\mathrm{E}$ and the line BG.Self-innovation car and the joint innovation car may be equilibrium at the scope of the point of $\mathrm{E}(016065581)$, and $\mathrm{F} 1 \mathrm{(T})=16065581-$ F2 (T) on (319514512870436) to G $(16065581,0)$.

Chongqing automotive industry innovation has created the potential users 16060000; External factors affecting selfinnovation is negative, the joint innovation has faster speed of market diffusion, but it is the negative influence from the i self-innovation products. The rate of market diffusion of 
self-innovation is not high, but diffusion was accelerated by the joint innovation for creatting market . By 2022, Two types of innovation will reach market equilibrium,Cumulative sales may be reached for stable at range from the point of E (016065581), and F2 (T) on B(319514512870436) to $\mathrm{G}(1065581,0)$

\section{CONCLUSION}

The joint innovation improve the speed of diffusion of self-innovation, on the contrary, self-innovation weaken the diffusion speed of innovation innovation. In the early days of innovation, two innovation will be uncertain of alternate growth, With the increase of the buyer, Market diffusion will have two different development trendsWhen the selfinnovation of automobile market is large enough, the joint car may be completely out of market. When self-innovation is weaker in the market, the diffusion of the two types innovation will reach equilibrium in a certain range.

Therefore, the ways of innovation can be further improved, The combination way of independent innovation and joint innovation, which is the new mode of technology innovation .The proportion of cooperation, by the specific products differ The proportion of cooperation will be differen t according to different products.We should encourage foreign auto companies to participate in the research and development in the process of independent innovation, in order to effectively promote the development of independent innovation.

\section{ACKNOWLEDGMENT}

This work was financially supported by the Chongqing Chongqing philosophy and Social Science Foundation (2012ZDGL010).

\section{REFERENCES}

[1] Bass, FM. A New Product Growth Model for Consumer Durable [J]. Management Science, 1969, 15: 215-227.

[2] Norton, John A., FM Bass. A Diffusion Theory Model of Adoption and Substitution for Successive Generations of High-technology Products[J] Management Science, 1987, 33(9):1069-1087.

[3] Comparison of Technological Innovation Pattern Based on Innovation Spillover in China , Zhang Jie

[4] Bucklin Louis P, Sengupta Sanjit. The Co-diffusion of Complementary Innovations: Supermarket Scanners and UPS Symbols [J], J. Product Innovation Management, 1993, 10: 148-60.

[5] Allan D. Shocker, Barry L. Bayus, Namwoon Kim, Product Complements and Substitutes in the Real World: the Relevance of "Other Product” [J], The Journal of Marketing, Vol.68(January 2004),28-40 